\title{
Krzysztof Krysieniel
}

\section{System wyborczy w Bośni i Hercegowinie - spojrzenie krytyczne ${ }^{1}$}

W tym roku mija 15 lat od zakończenia najkrwawszego konfliktu w Europie w drugiej połowie XX wieku, czyli wojny domowej w Bośni i Hercegowinie. Ten najbardziej dramatyczny rozdział w procesie rozpadu Socjalistycznej Federacyjnej Republiki Jugosławii przez ponad trzy lata przykuwał uwagę wspólnoty międzynarodowej, wykazując przy tym - szczególnie w odniesieniu do państw europejskich - jej niezdolność do podejmowania decyzji w sytuacjach kryzysowych. Dopiero zdecydowane - co nie oznacza, że niepozbawione błędów - zaangażowanie administracji prezydenta USA Billa Clintona przyniosło zakończenie działań zbrojnych. W dniu 21 listopada 1995 r. zostało parafowane porozumienie w bazie lotniczej Wright-Patterson koło Dayton w stanie Ohio. Wprawdzie uroczyste podpisanie miało miejsce w Paryżu 14 grudnia, to jednak właśnie to amerykańskie miasto stało się symbolem powojennego porządku w Bośni i Hercegowinie ${ }^{2}$.

Porozumienie z Dayton miało charakter umowy międzynarodowej. Oprócz stron bośniackiego konfliktu (Bośniaków³ , Serbów i Chorwatów) oraz przywódców Chorwacji i Jugosławii uczestniczyli w nim członkowie Grupy Kontaktowej (USA, Rosja, Wielka Brytania, Francja, RFN i Włochy) oraz Specjalny Negocjator Unii Europejskiej. Składało się z 11-stu niezbyt rozbudowanych artykułów oraz takiej samej liczby aneksów, zawierających szczegółowe informacje i regulacje $e^{4}$.

\footnotetext{
1 Artykuł jest zmodyfikowaną wersją referatu wygłoszonego na I Seminarium Młodych Badaczy Prawa Konstytucyjnego, które odbyło się w Mąchocicach Kapitulnych w dniach 11-12 marca $2010 \mathrm{r}$.

2 Pełna oficjalne nazwa porozumienia to General Dayton Peace Agreement (GDPA) - Ogólne Porozumienie Pokojowe z Dayton. Można też w literaturze spotkać skrót DPA.

3 Czyli mieszkańców Bośni i Hercegowiny wyznających islam, do 1993 r. Muzułmanów. Istnieje nieprzetłumaczalna na język polski - mimo prób wprowadzenia - różnica między określeniem wszystkich mieszkańców tego państwa bez względu na wyznanie (Bosanci) a wyznawcami islamu (Bošnjaci).

4 T. Gromes, Daytonski sporazum za Bosnu i Hercegovinu, [w:] Uvod u polički sistem Bosne $i$ Hercegovine - izabrani aspekti, pod red. S. Gavrić, D. Banović, C. Krause, Sarajewo 2009, s. 44. Pełen tekst porozumienia dostępny na oficjalnej stronie Wysokiego Przedstawiciela Wspólnoty Międzynarodowej (OHR) http://www.ohr.int/dpa/default.asp?content_id=379 (11.03.2010).
} 
Poszczególne aneksy obejmowały najważniejsze kwestie mające przyczynić się do ustabilizowania sytuacji w państwie. Do kluczowych bez wątpienia można zaliczyć Aneks nr IV (Konstytucję) oraz Aneks nr X (Cywilną implementację). Pierwszy $\mathrm{z}$ wyżej wymienionych zawierał tekst ustawy zasadniczej, drugi natomiast powoływał do życia instytucję Wysokiego Przedstawiciela Wspólnoty Międzynarodowej (The High Representative of International Community, $\mathrm{OHR}^{5}$ ), który miał nadzorować wprowadzania porozumienia w życie.

Analizując przyjęte w 1995 r. rozwiązania, można wskazać za Edinem Šarčeviciem na kilka charakterystycznych cech $^{6}$ :

a) uregulowanie materii prawno-konstytucyjnej porozumieniem międzynarodowym;

b) etnizację ustrojodawcy poprzez odsunięcie na plan dalszy abstrakcyjnego obywatela jako nosiciela władzy ustrojodawczej;

c) tymczasowość rozwiązań, przekształconą w trwały system prawno-konstytucyjny;

d) usankcjonowanie bezprawia i przekształcenie efektów konfliktu i zbrodni wojennych w stosunki publiczno-prawne;

e) etniczną demokrację, która wymaga osiągnięcia etnicznego porozumienia we wszystkich sprawach państwowych, połączoną z permanentnym konfliktem między przedstawicielami narodów konstytutywnych (Bośniakami, Serbami i Chorwatami);

f) etniczny determinizm przy podejmowaniu decyzji w organach władzy;

g) aktywną obecność czynnika zewnętrznego przy kierowaniu państwem;

h) utratę suwerenności wewnętrznej poprzez osłabianie organów władzy państwowej;

i) zawieszenie aktywnej ochrony oficjalnie zaakceptowanych praw człowieka;

j) sprzeczności między deklarowanymi pryncypiami a podstawowymi rozwiązaniami konstytucyjnymi.

Porozumienie z Dayton miało skutkować realizacją dwóch podstawowych celów: zakończeniem działań zbrojnych oraz odbudową państwa jako demokratycznej wspólnoty politycznej ${ }^{7}$. O ile w Bośni i Hercegowinie udało się pod presją sił międzynarodowych wprowadzić pokój, o tyle znacznie trudniej kształtują

5 Od lutego 2002 r. Wysoki Przedstawiciel pełni jednocześnie funkcję Specjalnego Przedstawiciela Unii Europejskiej w Bośni i Hercegowinie (EU's Special Representative in BiH).

6 E. Šarčević, Deytonski ustav: karakteristike i karakteristični problemi, Sarajevo 2009, s. 85.

7 M. Kasapović, Bosna i Hercegovina: podijeljeno društvo i nestabilna država, Zagreb 2005, s. 13. 
się struktury i instytucje wspólnego państwa. Opracowane przez amerykańskich prawników ${ }^{8}$ założenia porządku prawno-konstytucyjnego dalekie są od doskonałości, co zresztą stosunkowo szybko stało się widoczne, a z czasem stały się wręcz główną przeszkodą dla demokratycznego rozwoju oraz powstania społeczeństwa obywatelskiego'.

Do podstawowych elementów dysfunkcjonalnych obecnych w systemie politycznym Bośni i Hercegowiny można zaliczyć ${ }^{10}$ :

a) stworzenie dwóch jednostek (entiteti) o odmiennej strukturze terytorialno-administracyjnej - scentralizowanej Republiki Serbskiej (obejmującej 49\% obszaru państwa) oraz Federacji Bośni i Hercegowiny ${ }^{11}$, składającej się z dziesięciu kantonów (51\%);

b) przekształcenie Bośni i Hercegowiny w półprotektorat poprzez powołanie instytucji Wysokiego Przedstawiciela Wspólnoty Międzynarodowej; w grudniu 1997 r. rozszerzono jego kompetencje o tzw. uprawnienia bońskie, co dało mu możliwość dowolnego kształtowania prawa (w tym konstytucji jednostek oraz ustaw), tworzenia i obsadzania organów władzy i urzędów, dymisjonowania polityków, wetowania kandydatów na stanowiska publiczne oraz karania partii politycznych ${ }^{12}$;

c) brak decyzji co do przynależności terytorialnej strategicznie położonego miasta Brčko; ostatecznie w 1999 r. utworzony został Dystrykt Brčko, posiadający własny statut i organy władzy, podlegający bezpośrednio Sarajewu; dopiero w 2009 r. istnienie tej specyficznej jednostki zostało uwzględnione w konstytucji;

d) słabe władze centralne, co przełożyło się np. na trudności z ujednoliceniem wojska i służb policyjnych, kontrolą graniczną, wprowadzeniem wspólnej waluty, a nawet paszportów;

8 Oryginalny tekst konstytucji został opracowany tylko w języku angielskim, a samej ustawy zasadniczej w żaden sposób nie zaakceptował ani bośniacki parlament, ani naród w referendum.

9 A. Mujkić, Mi, građani Etnopolisa, Sarajevo 2007, s. III.

10 N. Duraković, Ustavne promjene u Bosni i Hercegovini, „Godišnjak Fakulteta političkih nauka” nr 1, 2006, s. 104-105.

$11 \mathrm{Z}$ powodu kuriozalnego nazewnictwa (czyli nazwania jednego z podmiotów federacji właśnie mianem Federacji) w pracy nie będzie używane określenie,federalny” w stosunku do centralnych organów władzy, gdyż mogłoby to zaciemnić obraz struktury terytorialno-administracyjnej.

${ }_{12}$ T.K. Vogel, Bosnia and Herzegovina: The Challenge of Legitimacy, „Working Paper” nr 2, 2006, s. 6. 
e) różnice w systemach politycznych Republiki Serbskiej i Federacji, co prowadzi do dyskryminacji na tle narodowościowym, religijnym, a nawet w szkolnictwie czy ekonomii;

f) niezwykle skomplikowany sposób podejmowania decyzji na poziomie władz centralnych oraz jednostek, zawierający możliwość zastosowania weta przez przedstawicieli któregoś z narodów konstytutywnych w obronie tzw. żywotnych (witalnych) interesów ${ }^{13}$.

Jednym z najbardziej wyrazistych przykładów nietypowych, a właściwie niedemokratycznych rozwiązań prawnych, leżących u podstaw systemu politycznego Bośni i Hercegowiny, jest obowiązująca ordynacja wyborcza.

Pierwsze wolne i demokratyczne wybory w Bośni i Hercegowinie odbyły się późną jesienią 1990 r. Sytuacja w tej republice była o tyle odmienna w porównaniu $\mathrm{z}$ innymi podmiotami federacji jugosłowiańskiej, że wyłaniano parlament dwuizbowy (Skupsztinę), a nie - jak np. w Chorwacji czy Serbii - trzyizbowy. Radę Obywatelską oraz Radę Gmin powołano na mocy poprawki LXX do konstytucji republikańskiej ${ }^{14}$. W odbytych na przełomie listopada i grudnia wyborach tryumfowały ugrupowania nacjonalistyczne: reprezentująca Muzułmanów Partia Akcji Demokratycznej (SDA), Serbska Partia Demokratyczna (SDS) oraz Chorwacka Wspólnota Demokratyczna (HDZ). Wysokie poparcie dla tych ugrupowań przełożyło się na zdobycie przez te partie ponad $84 \%$ miejsc w Skupsztinie. Wyniki poszczególnych ugrupowań nacjonalistycznych pokrywały się praktycznie z etniczną i religijną strukturą mieszkańców republiki, zresztą ordynacja oparta została na zasadzie „klucza etnicznego”, z założonym odchyleniem do $15 \%{ }^{15}$.

Równocześnie odbyły się bezpośrednie wybory do kolegialnego Prezydium Republiki. W siedmioosobowym organie zasiadło po dwóch przedstawicieli $\mathrm{Mu}$ zułmanów, Serbów i Chorwatów oraz jeden przedstawiciel innych narodowości.

Kolejne wybory odbyły się dopiero we wrześniu 1996 r., czyli po zakończeniu wojny. Ich przeprowadzenie zostało uzgodnione w Aneksie nr III porozumienia z Dayton. Decydującą rolę odegrała wspólnota międzynarodowa, przeprowadzając elekcję do organów władzy na wszystkich szczeblach: od centralnego, poprzez organy jednostek, kantonów (w Federacji Bośni i Hercegowiny), samorządów

13 Obszernie na ten temat zob.: Proces odlučivanja u Parlamentarnoj skupštini Bosne i Hercegovine. Stanje - komparativna rješenja - prijedlozi, pod red. I. Marić, K. Trnka, Sarajevo 2009.

14 O. Ibrahimagić, S. Kurtćehajić, Politički sistem Bosne i Hercegovine, Sarajevo 2002, s. 144.

15 F. Bieber, Bosna i Hercegovina poslije rata. Politčki sistem u podjeljenom društvu, Sarajevo 2008, s. 23-24. 
lokalnych oraz Dystryktu Brčko. Z jej ramienia proces wyborczy nadzorowała OBWE, która powołała Tymczasową Komisję Wyborczą, nadzorującą procedurę wyborczą od rejestracji wyborców po ogłoszenie rezultatów ${ }^{16}$.

Konstytucja przewidywała utworzenie dwuizbowego parlamentu (Skupsztiny Parlamentarnej), składającego się z Izby Przedstawicielskiej, wybieranej w sposób bezpośredni, oraz Izby Narodów, której skład wyłaniają parlamenty podmiotów. Do tej pierwszej przyjęto ordynację opartą na systemie proporcjonalnym, ze sztywnymi listami partyjnymi. Przeliczanie głosów na mandaty odbyło się z zastosowaniem metody Hare’a. Oprócz Izby Przedstawicielskiej bezpośrednio wybierano również trzyosobowe Prezydium. O skali problemów związanych z przygotowaniem procesu wyborczego niech świadczy chociażby to, iż co najmniej milion obywateli zmienił w trakcie wojny miejsce pobytu, z czego znaczna część znalazła się poza granicami Bośni i Hercegowiny ${ }^{17}$. W pierwszych wyborach zdecydowanie triumfowali przedstawiciele partii nacjonalistycznych, tych samych, które zdominowały elekcję w 1990 r. - zdobyli łącznie 96\% głosów. Kolejne elekcje parlamentarne (do 2002 r.) odbywały się co dwa lata, w przypadku Prezydium natomiast tylko pierwszy skład miał dwuletnią kadencję - od 1998 r. wydłużono ją do czterech lat.

Dopiero w listopadzie 2001 r. utworzona została Komisja Wyborcza Bośni i Hercegowiny $18^{18}$, którą przemianowano w kwietniu 2006 r. na Centralną Komisję Wyborczą. Odpowiada ona za ogłoszenie, przygotowanie, przeprowadzenie i opublikowanie wyników wyborów. Jej skład oparty jest na odpowiednim parytecie narodowościowym, a tworzy ją siedmiu członków: po dwóch Bośniaków, Serbów oraz Chorwatów oraz jeden przedstawiciel innej narodowości.

Centralna Komisja Wyborcza funkcjonuje na mocy przyjętego w sierpniu 2001 r. Prawa wyborczego Bośni i Hercegowiny ${ }^{19}$. W następnym roku praktycznie własnymi siłami zostało przeprowadzone głosowanie - OBWE odgrywała przede wszystkim rolę obserwatora.

W Bośni i Hercegowinie wybory przeprowadzane są do szeregu organów władzy ustawodawczej i wykonawczej na różnych poziomach - centralnym, jednostek, kantonalnym (w Federacji) oraz lokalnym. Ogólna ich liczba jest imponująca, po-

16 T. Ljubić, D. Marko, Izbori i izborni sistem, [w:] Uvod u polički sistem..., s. 317.

17 N. Miličević, Analiza izbornih rezultata u Bosni i Hercegovini, www.aimpress.ch (7.06.1996).

18 Pierwszy skład został powołany przez Wysokiego Przedstawiciela Wspólnoty Międzynarodowej. Tworzyło go m.in. trzech cudzoziemców!

19 Izborni zakon Bosne i Hercegovine (Prečišćeni tekst), „Službeni glasnik BiH” nr 24, 2006. Pełny, stale uaktualniany, choć nieoficjalny tekst ordynacji znajduje się na stronie Centralnej Komisji Wyborczej: http://www.izbori.ba/documents/ZAKONI/POIZpw110508.pdf. (11.03.2010) 
nieważ wyłania się np. aż 14 parlamentów (centralny, dwa w jednostkach, 10 kantonalnych w Federacji oraz w Dystrykcie Brčko). W większości przypadków wybory oparte są na zasadzie powszechności i bezpośredniości, choć nierzadkie są też przypadki elekcji pośredniej. Jednak niezależnie od przyjętej metody wyłaniania składu, widoczna jest wszechobecność czynnika etnicznego jako podstawowego determinanta procedury wyborczej.

Do najważniejszych organów władzy, które posłużą jako przykłady dla przedstawienia specyfiki bośniackiego systemu wyborczego, należą: Prezydium oraz Skupsztina Parlamentarna (na szczeblu centralnym), Skupsztina Dystryktu Brčko, Parlament Federacji Bośni i Hercegowiny oraz Ludowa Skupsztina Republiki Serbskiej i Rada Narodów, jak też prezydenci obu jednostek i ich zastępcy (na szczeblu podmiotów).

Prezydium Bośni i Hercegowiny jest organem trzyosobowym, składającym się z Bośniaka i Chorwata (wybieranych w wyborach powszechnych i bezpośrednich na obszarze Federacji) oraz Serba (wybieranego w ten sam sposób w Republice Serbskiej). Głosowanie odbywa się razem z wyborami parlamentarnymi. Wyborca głosujący w Federacji może poprzeć tylko jednego kandydata - Bośniaka lub Chorwata. Zwyciężają ci kandydaci, którzy otrzymali największą liczbę głosów spośród startujących z grona tego samego narodu konstytutywnego (rozdział 8 ordynacji wyborczej).

Skupsztina Parlamentarna Bośni i Hercegowiny składa się z Izby Przedstawicielskiej oraz Izby Narodów ${ }^{20}$. Izba Przedstawicielska, licząca 42-óch posłów, wybierana jest w sposób bezpośredni i powszechny, w oparciu o system proporcjonalny, przy czym 28-u (2/3) deputowanych pochodzi z Federacji, a 14-stu (1/3) z terenu Republiki (rozdział 9 ordynacji). Spośród posłów z Federacji 21 wybiera się w pięciu okręgach wielomandatowych, a pozostałe siedem miejsc to tzw. mandaty kompensacyjne ${ }^{21}$, obliczane $\mathrm{w}$ dość skomplikowany sposób. Podobnie ma się rzecz w przypadku reprezentantów Republiki - dziewięciu wyłania się w trzech okręgach wielomandatowych, a pięć to mandaty kompensacyjne. Do podziału mandatów używa się metody Sainte-Laguë. Przekroczenie progu 3\% głosów w pojedynczym okręgu umożliwia udział w podziale mandatów, z kolei prawo do man-

20 Warto zwrócić uwagę na następujący fakt: w Bośni i Hercegowinie nie zastosowano klasycznego dla państw federalnych podejścia do dwuizbowości, gdyż izba druga nie jest reprezentantem podmiotów (czyli jednostek), lecz narodów.

21 Ten typ mandatów jest obecny przy wyborze znacznej części organów kolegialnych, a w założeniu ma zagwarantować równą reprezentację przedstawicieli wszystkich narodów konstytutywnych, czyli Bośniaków, Serbów i Chorwatów. 
datów kompensacyjnych uzyskują już tylko partie i koalicje wyborcze, które także uzyskały ponad $3 \%$ głosów, lecz na terenie całej jednostki.

Członków Izby Narodów wyłania się w odmienny sposób, gdyż wybierani są w sposób pośredni przez parlamenty jednostek. Federację Bośni i Hercegowiny reprezentuje dziesięciu deputowanych, po równo Chorwatów i Bośniaków, a wyboru dokonują odpowiednio chorwaccy i bośniaccy członkowie Izby Narodów - jednej z izb Parlamentu Federacji Bośni i Hercegowiny. Pięciu Serbów natomiast deleguje Skupsztina Ludowa Republiki Serbskiej. Prawo głosu posiada każdy poseł, głosowanie jest tajne, a mandaty dzieli się proporcjonalnie, również z zastosowaniem metody Sainte-Laguë.

Skupsztinę Dystryktu Brčko tworzy 31 deputowanych, z czego dwóch musi pochodzić z grona mniejszości narodowych ${ }^{22}$. Wybory mają charakter proporcjonalny, przy czym każdy z narodów konstytutywnych ma zapewnione co najmniej trzy mandaty, co jest sprzeczne ze stanowiskiem przedstawiciela wspólnoty międzynarodowej, nadzorującego Brčko ${ }^{23}$. Podział miejsc w Skupsztinie odbywa się na podobnych zasadach, jakie obowiązują na poziomie centralnym (metoda SainteLaguë, próg 3\%).

Parlament Federacji Bośni i Hercegowiny składa się z dwóch izb: Izby Przedstawicielskiej, liczącej 98-u deputowanych, oraz Izby Narodów, do której parlamenty kantonów (w Federacji jest ich 10) delegują 58-u przedstawicieli. Izbę Przedstawicielską wybiera się w sposób bezpośredni i powszechny. Zgodnie z ordynacją, mandaty kompensacyjne muszą stanowić od 23 do $27 \%$ ogólnej liczby ${ }^{24}$, pozostałe rozdzielane są $\mathrm{w}$ wielomandatowych okręgach wyborczych. W obu przypadkach obowiązują te same zasady przeliczania głosu na mandaty (metoda Sainte-Laguë, próg zaporowy $3 \%)$. Każdy z narodów konstytutywnych musi mieć co najmniej czterech posłów w tej izbie. Z kolei w Izbie Narodów Federacji Bośniacy, Serbowie i Chorwaci mają po 17-stu deputowanych, dodatkowo przedstawiciele innych narodów są reprezentowani przez siedmiu członków (rozdział 10. A i 10.B ordynacji).

Parlament Republiki Serbskiej jest specyficznym przykładem organu ustawodawczego. Składa się z dwóch izb: Skupsztiny Ludowej oraz Rady Narodów. Tylko ta pierwsza uczestniczy w pełni w procedurze legislacyjnej, rolą drugiej natomiast

22 Szczegółowe postanowienia zawarte są w Ustawie wyborczej Dystryktu Brčko, „Službeni glasnik Brčko distrikta” nr 17,2008.

23 F. Bieber, op.cit., s. 156.

24 Dokładnego określenia liczby mandatów kompensacyjnych dokonuje Centralna Komisja Wyborcza na podstawie skomplikowanego wzoru. 
jest kontrola, czy stanowione przepisy nie naruszają praw narodów konstytutywnych $^{25}$. Do Skupsztiny wybiera się w głosowaniu bezpośrednim i powszechnym 83-ech posłów, przy czym każdy naród konstytutywny musi ich mieć co najmniej czterech. Terytorium Republiki podzielone jest na co najmniej sześć okręgów wielomandatowych, a ich ostateczna liczba zależy od obliczeń dokonanych przez Centralną Komisję Wyborczą. Pozostałe procedury i zasady są identyczne z wcześniej już omówionymi. W przypadku Rady Narodów, w jej skład wchodzi 28-u delegatów, po ośmiu Bośniaków, Serbów oraz Chorwatów, a także czterech przedstawiciele innych narodowości. Ich wyboru dokonują właściwe kluby narodowe funkcjonujące w Skupsztinie Ludowej (rozdział 11 i 11.A ordynacji).

Prezydent Federacji Bośni i Hercegowiny i jego dwaj zastępcy wyłaniani są w drodze wyborów pośrednich. Klub poselski każdego z narodów konstytutywnych desygnuje co najmniej jednego kandydata. Tworzy się zatem listę (bądź kilka list), na której umieszczone są trzy nazwiska. Wygrywa ta z nich, która uzyska bezwzględną większość głosów w Izbie Przedstawicielskiej Federacji, a następnie taką samą większość w drugiej izbie (ale obejmującą ponad połowę głosów deputowanych z każdego narodu konstytutywnego). Funkcję prezydenta pełni przez rok każdy ze zwycięskiej listy (rozdział 9.A ordynacji).

Inaczej wygląda wyłonienie prezydenta Republiki Serbskiej. Wybory mają charakter powszechny i bezpośredni, a zwycięża ten kandydat, który uzyska największą liczbę głosów (dotychczas wygrywali tylko Serbowie, gdyż stanowią ponad 90\% ludności podmiotu). Jego dwoma zastępcami zostają przedstawiciele pozostałych narodów konstytutywnych, którzy uzyskali największe poparcie (rozdział 12 ordynacji). Taki sposób wyboru został wprowadzony na mocy decyzji Wysokiego Przedstawiciela w $2002 \mathrm{r}^{26}$

W systemie wyborczym Bośni i Hercegowiny można wskazać wiele rozwiązań, które stoją w sprzeczności z podstawowymi nieraz zasadami demokracji, jak też zawierają liczne kontrowersyjne postanowienia. Dotyczy to zarówno procedury uchwalenia ordynacji, jak i samych następstw prawnych, będących następstwem jej obowiązywania.

Analizując okoliczności uchwalania obowiązujących od 1995 r. ordynacji, należy zwrócić uwagę na to, że były one w decydującej mierze efektem dyktatu wspólnoty międzynarodowej. Aneks III porozumienia z Dayton regulował podstawowe założenia, które miały lec u podstaw prawa wyborczego, a stronom konfliktu po-

25 T. Ljubić, D. Marko, op.cit., s. 328.

26 Ibidem. 
zostało jedynie zaakceptować zaproponowane rozwiązania. Kolejne elekcje odbywały się pod pełną kontrolą przedstawicieli OBWE. Kiedy w 2001 r. Skupsztina Parlamentarna przyjęła wreszcie Prawo wyborcze Bośni i Hercegowiny, oparto je na projekcie opracowanym przez wspólnotę międzynarodową, z minimalnym udziałem najbardziej zainteresowanych stron ${ }^{27}$.

Brak konsekwencji widoczny jest już na poziomie konstytucji. W art. I/2 znaleźć można sformułowanie, iż: „Bośnia i Hercegowina jest państwem demokratycznym, które funkcjonuje zgodnie $\mathrm{z}$ ustawami i podstawowymi zasadami wolnych i demokratycznych wyborów”. Tymczasem z walki wyborczej do szeregu najważniejszych organów władzy państwowej (np. Prezydium, Izby Narodów, prezydium Skupsztiny Parlamentarnej) wykluczeni są ci obywatele Bośni i Hercegowiny, którzy nie są etnicznymi Bośniakami, Serbami lub Chorwatami. Tym samym przedstawiciele ponad 20-stu mniejszości narodowych, obecnych według spisu powszechnego z $1991 \mathrm{r}$. na terenie Bośni i Hercegowiny, pozbawieni są fundamentalnych, demokratycznych praw $^{28}$.

Innym przykładem wewnętrznej sprzeczności postanowień konstytucji jest zestawienie art. IX/3 („Przedstawiciele zasiadający w instytucjach Bośni i Hercegowiny wyrażają i reprezentują ogólny skład narodów Bośni i Hercegowiny”) z art. IV i V. Zgodnie z nimi, narody są podzielone według przynależności do jednostek (Federacji lub Republiki) i to determinuje prawo do posiadania pełnych praw wyborczych $^{29}$. Skutek jest taki, iż Bośniacy i Chorwaci mieszkający na terenie Republiki Serbskiej nie mogą głosować na przedstawicieli swoich narodów w wyborach do Prezydium, podobnie jak Serbowie z obszaru Federacji.

Wciąż obecna - mimo upływu 15-stu lat od zakończenia konfliktu - atmosfera podziałów etnicznych, strachu oraz wzajemnej niechęci (czasami wręcz nienawiści) uniemożliwia przeprowadzenie wyborów, w których obywatele w pełni wolny i nieskrępowany sposób wyraziliby swoje preferencje polityczne. Nie sprzyja temu etniczna homogenizacja i podziały partyjno-rodzinno-klanowe, które zmuszają członków każdej zamkniętej społeczności do głosowania zgodnie z wolą otoczenia $^{30}$.

27 N. Šačić, Konstitucionalne nedorečenosti kao izvori konfliktnosti u BiH, [w: ] Politička i konstitucionlna integracija duboko podeljenih društava, pod red. M. Podunavac, Beolgrad 2008, s. 92.

28 Ć. Sadiković, Bosna i Hercegovina u evropskim javnom poretku, „Pregled” nr 3-4, 2007, s. 21.

29 O. Ibrahimagić, Dejtonski put Bosne u Evropu, „Pregled” nr 1-2, 2003, s. 24.

30 A. Mujkić, op.cit., s. 1. 
W Bośni i Hercegowinie abstrakcyjny, pojedynczy obywatel nie jest wartością podstawową. Jego pozycja tylko wtedy staje się istotna, jeśli jest pochodną przynależności etnicznej. Wartością najważniejszą, konstytuującą i fundamentalną jest kolektyw, występujący jako kluczowy podmiot polityczny ${ }^{31}$. Stąd częste przytaczanie zarówno w konstytucji, jak i ordynacji wyborczej pojęcia „narodów konstytucyjnych”. Przedstawiciele innych narodów (np. Czarnogórcy, Albańczycy czy Żydzi ${ }^{32}$ ) pozbawieni są w świetle prawa części praw wyborczych tylko ze względu na pochodzenie.

Mimo obecnego w konstytucji odwołania do Europejskiej Konwencji o Ochronie Praw Człowieka i Podstawowych Wolności (art. II/2) i nadania jej postanowieniom priorytetu nad wszelkimi ustawami, jak też odwołania się do czternastu innych konwencji dotyczących praw człowieka (Aneks I do konstytucji), bośniacka ustawa zasadnicza oraz ordynacja wyborcza w wielu miejscach łamią przepisy tychże porozumień międzynarodowych ${ }^{33}$. Szczególnie dotyczy to art. 14 wspomnianej konwencji, zakazującego jakichkolwiek form dyskryminacji.

Postanowienia wprowadzające dyskryminację ze względu na przynależność etniczną i miejsce zamieszkania nie zostały zmienione pomimo licznych apeli oraz presji wywieranej ze strony przedstawicieli wspólnoty międzynarodowej ${ }^{34}$. Jako przykład można wskazać rezolucję nr 1384, przyjętą przez Radę Europy, a popartą przez przedstawicieli administracji USA ${ }^{35}$. Podjęta została także próba zaskarżenia niektórych postanowień konstytucji oraz ordynacji wyborczej do Europejskiego Trybunału Praw Człowieka. Dwaj obywatele Bośni i Hercegowiny - Dervo Sejdić (przedstawiciel mniejszości romskiej) oraz Jakob Finci (z mniejszości żydowskiej) złożyli w 2006 r. skargę ze względu na pozbawienie ich praw wyborczych w wyborach do Prezydium oraz Izby Narodów. Trybunał wydał ostatecznie w grudniu 2009 r. postanowienie, w którym uznał słuszność przedłożonej skargi, potwierdzając tym samym sprzeczność części bośniackiej konstytucji i ordynacji z prawem międzynarodowym ${ }^{36}$.

31 Ibidem, s. 6-7.

32 Można spotkać się z opinią, że Bośnia i Hercegowina jest ostatnim w Europie państwem antysemickim, gdyż Żydzi nie mogą ubiegać się o np. funkcję członka Prezydium.

33 E. Šarčević, op.cit., s. 73-74; O. Ibrahimagić, op.cit., s. 25.

34 Jest to jednak hipokryzja, gdyż krytykowane przepisy zostały w dużej mierze wcześniej narzucone przez tę samą wspólnotę międzynarodową.

35 Ć. Sadiković, op.cit., s. 36.

36 Sejdić i Finci protiv Bosne i Hercegovine (Aplikacije br. 27996/06 i 34836/06), www.ceo. $\mathrm{ba} /$ web/dokumenti/presudaBIH.doc. (11.03.2010). 
Obowiązujące w Bośni i Hercegowinie rozwiązania trudno nazwać w pełni demokratycznymi, dlatego od pewnego czasu używa się określenia „etnokracja”. Jest to taka odmiana systemu politycznego, w której decydującą rolę odgrywa kwalifikowane prawo do pełnego obywatelstwa, oparte na przynależności etnicznej, wyróżnionej na podstawie rasy, pochodzenia, religii lub języka. Podstawową wartością jest dążenie danej grupy etnicznej do sprawowania kontroli nad najważniejszymi instrumentami władzy państwowej, w tym do wyraźnej nadreprezentacji jej przedstawicieli w różnego typu organach i instytucjach decyzyjnych. Pozostające w mniejszości grupy etniczne mogą być systematycznie dyskryminowane, prawdopodobne jest także doświadczanie represji lub prześladowań ze strony zinstytucjonalizowanego aparatu władz państwowych. Etnokrację charakteryzuje system kontroli - prawnych, instytucjonalnych i fizycznych narzędzi władzy uważanych za konieczne dla zabezpieczenia dominacji etnicznej ${ }^{37}$. Można ją także przedstawić jako „(...) sytuację w państwie, w której rządzi ethnos; sytuację, w której etniczna przynależność decyduje o politycznym statusie. Jej rzeczywisty sens nie odnosi się do rządów konkretnego narodu w wielonarodowej wspólnocie, ale do samej możliwości, że naród jako ethnos generalnie może rządzić. (...) Wszystko to konkretyzuje się porządkiem konstytucyjnym. Etnokracja w każdym przypadku oznacza pozbawienie abstrakcyjnego obywatela fundamentalnej roli w państwie i przekazanie jej w decydującym stopniu narodowi i jego potrzebom"38.

\section{Summary}

\section{Electoral system in Bosnia and Herzegovina - critical outlook}

The electoral law in Bosnia and Herzegovina differs significantly from commonly accepted standards operating in democratic state. During the parliamentary or presidential elections, the citizens who do not belong to one of constituent states (Bosnians, Serbs, Croats) are deprived of basic rights. The solutions established in 1995, and later only slightly modified, eventually caused the end of war but did not introduce fully democratic solutions. Even more surprising is the fact that the authors of constitutional order, including election law, are representatives of in-

37 N.A Butenschøn, Politics of Ethnocracies, artykuł dostępny na oficjalnej stronie internetowej Uniwersytetu w Oslo http://www.statsvitenskap.uio.no/ansatte/serie/notat/fulltekst/0193/ (11.03.2010).

38 E. Šarčević, op.cit., s. 168. 
ternational community, mostly American lawyers. Unfortunately, in Bosnia and Herzegovina national communities, that are treated by the law as main entity of political life, are far more important than an ordinary citizen. 